\title{
DAYA TERIMA DAN KADAR ZAT BESI NUGGET HATI AYAM DENGAN KOMBINASI TEMPE SEBAGAI PANGAN OLAHAN SUMBER ZAT BESI
}

\author{
Asti Fauziah1, Roifah Fajri2 ${ }^{*}$, Restu Amalia Hermanto ${ }^{2}$ \\ 1,2,3 Sekolah Tinggi Ilmu Kesehatan Holistik \\ *Korespondensi: Jl. Veteran No. 272 Ciseureuh Purwakarta Email: roifah@stikesholistic.ac.id
}

\begin{abstract}
ABSTRAK
Latar belakang : Prevalensi anemia di Indonesia masih tinggi yaitu pada remaja putri sebesar 26,50\%, wanita usia subur sebesar 26,9\%, ibu hamil sebesar 40,1\% dan balita sebesar 47,0\%. Anemia dapat disebabkan karena kekurangan konsumsi makanan sumber zat besi. Salah satu upaya yang dapat dilakukan yaitu dengan perbaikan pangan dan gizi dengan meningkatkan konsumsi pangan yang memiliki kandungan zat besi. Produk nugget hati ayam kombinasi tempe dapat menjadi produk pangan olahan yang dapat dikonsumsi untuk meningkatkan asupan zat besi sebagai upaya pencegahan anemia.

Tujuan : Penelitian ini bertujuan untuk mengetahui daya terima dan kadar zat besi nugget hati ayam kombinasi tempe.

Metode : Rancangan percobaan menggunakan Rancangan Acak Lengkap (RAL) dengan tiga kali pengulangan perlakuan, dua kali pengulangan analisis serta lima taraf perlakuan diantaranya perbandingan antara hati ayam dan tempe 10\%: 90\% (F1), 30\% : 70\% (F2), 50\% : 50\% (F3), 30\% : 70\% (F4) dan 90\% : 10\% (F5). Analisis data diuji menggunakan Kruskall Wallis dilanjutkan dengan Mann Whitney serta One Way Anova. Kadar zat besi dianalisis menggunakan metode Spektrofotometri Serapan Atom (SSA). Daya terima produk dilakukan menggunakan uji hedonik.

Hasil : Terdapat perbedaan daya terima nugget dari berbagai rasio hati ayam dan tempe pada parameter warna $(p=0.000)$, aroma $(p=0.017)$, tekstur $(p=0.049)$ dan rasa $(p=0.000)$. Namun, tidak terdapat perbedaan kadar zat besi nugget dari berbagai rasio hati ayam dan tempe $(p=0.877)$.

Simpulan : Terdapat perbedaan daya terima nugget dari berbagai rasio hati ayam dan tempe dan tidak terdapat perbedaan kadar zat besi nugget dari berbagai rasio hati ayam dan tempe. Berdasarkan hasil uji daya terima, diperoleh formula yang paling disukai diantaranya F3, F2 dan F4.
\end{abstract}

Kata kunci : Daya terima, kadar zat besi, nugget hati ayam kombinasi tempe.

\section{ABSTRACT}

Background: The prevalence of anemia in Indonesia is still high, in girl adolescents $26.50 \%$, childbearing women $26.9 \%$, pregnant women $40.1 \%$ and infants $47 \%$. Anemia can caused by inadequate dietary iron intake from foods. One of the effort that can be done is to improve food and nutrition by increasing consumption of foods containing iron. Chicken liver nugget with combination tempeh can consumed as processed food that increase iron intake as an effort to prevent anemia.

Objective: This research aims to studying the acceptability and iron content of chicken liver nuggets with combination tempeh.

Methods: The experimental design using Completely Randomized Design (CRD) with three repetitions of treatment, two repititions of analysis and five treatment levels with ratio between chicken liver and tempeh 10\%: 90\% (F1), 30\%: 70\% (F2), 50\%: 50\% (F3), 30\%: 70\% (F4) and 90\% : 10\% (F5). Data analysis was tested using Kruskal Wallis followed by 
Mann Whitney and One Way Anova. Iron levels were analyzed using a Atomic Absorption Spectrophotometry (AAS). Acceptance test of the product was done using a hedonic test.

Results: There are differences in the acceptability of nuggets from various ratios of chicken liver and tempeh in color parameter $(p=0,000)$, odor $(p=0.017)$, texture $(p=0.049)$ and taste $(p=0,000)$. However, there are no differences in iron content from various ratios of chicken liver and tempeh ( $p=0.877)$.

Conclusion: There are differences in the acceptability of nuggets from various ratios of chicken liver and tempeh and there is no differences in iron nugget levels from various ratios of chicken liver and tempeh. Based on the results of the acceptability, the most preferred formulas were obtained including F3, F2 and F4.

Keywords: Acceptability, iron content, chicken liver nuggets with combination tempeh

\section{PENDAHULUAN}

Prevalensi anemia di Indonesia berdasarkan hasil Riset Kesehatan Dasar tahun 2013, yaitu pada remaja putri sebesar $26,50 \%$, wanita usia subur sebesar $26,9 \%$, ibu hamil sebesar $40,1 \%$ dan balita sebesar 47,0\%. ${ }^{1}$ Anemia dapat menimbulkan dampak negatif pada kelompok yang rentan mengalami anemia. ${ }^{2}$

Masalah anemia dapat memberikan dampak menurunkan kualitas sumber daya manusia, maka salah satu cara untuk membantu mencegah dan menanggulangi anemia adalah dengan upaya perbaikan pangan dan gizi dengan meningkatkan konsumsi pangan yang mengandung zat besi melalui makanan olahan. Salah satu produk makanan olahan yang digemari oleh masyarakat semua kalangan usia yaitu nugget. ${ }^{3}$

Nugget biasanya dibuat dengan memanfaatkan daging ayam, namun dalam penelitian ini nugget dibuat dengan memanfaatkan hati ayam yang merupakan salah satu sumber zat besi. Dalam Tabel Komposisi Pangan Indonesia (TKPI), hati ayam mengandung zat besi sebesar 15,8 $\mathrm{mg} / 100$ gram, lebih tinggi jika dibandingkan dengan sumber hewani lainnya. ${ }^{4}$ Dalam upaya meningkatkan nilai gizi pada nugget hati ayam, menambah citarasa nugget serta mengurangi kebutuhan bahan dasar daging, maka bahan dasar nugget ditambahkan dengan bahan pangan lokal yaitu tempe.

Berdasarkan latar belakang tersebut, penelitian ini bertujuan untuk mengetahui daya terima dan kadar zat besi nugget hati ayam kombinasi tempe sebagai produk makanan olahan sumber zat besi. Hasil penelitian ini diharapkan dapat menjadi bahan informasi ilmiah dalam upaya untuk pengembangan produk nugget hati ayam dan tempe yang merupakan produk makanan olahan sumber zat besi sebagai salah satu upaya dalam pencegahan anemia.

\section{METODE PENELITIAN}

Bahan yang digunakan dalam pembuatan nugget adalah hati ayam, tempe, tepung terigu, es batu, minyak goreng, tepung panir, telur dan bumbu yang terdiri dari merica bubuk, ketumbar bubuk, bawang putih, bawang merah, pala bubuk, garam dan gula pasir. Bahan yang digunakan dalam analisis kadar zat besi adalah larutan asam nitrat pekat (HNO3 pekat), aquadest, larutan induk besi, $\mathrm{HCl}$, larutan standar besi dan larutan blanko. Alat yang digunakan dalam pembuatan nugget adalah blender, timbangan, pisau, sendok, garpu, piring, mangkuk, baskom, loyang, panci, kompor, freezer, wajan, spatula, plastik pembungkus, sarung tangan plastik dan talenan. Alat yang digunakan dalam analisis kadar zat besi adalah cawan porselin, timbangan analitik, beaker glass, microwave digestion, labu ukur, pipet tetes, spektrofotometer serapan atom. Alat yang digunakan dalam uji daya terima diantaranya plastik pembungkus nugget, formulir uji dan alat tulis. 
Formula nugget hati ayam kombinasi tempe dirancang berdasarkan percobaan awal yang telah dilakukan serta perhitungan estimasi kandungan zat gizi.
Rasio kombinasi bahan baku nugget hati ayam dan tempe pada penelitian ini disajikan pada Tabel 1.

Tabel 1. Rasio Hati Ayam dan Tempe

\begin{tabular}{cc}
\hline Formula & Hati Ayam : Tempe \\
\hline F1 & $10 \%: 90 \%$ \\
F2 & $30 \%: 70 \%$ \\
F3 & $50 \%: 50 \%$ \\
F4 & $70 \%: 30 \%$ \\
F5 & $90 \%: 10 \%$ \\
\hline
\end{tabular}

Formula nugget hati ayam kombinasi tempe dalam penelitian ini disajikan pada tabel 2. ${ }^{5}$

Tabel 2. Formulasi Nugget Hati Ayam dan Tempe

\begin{tabular}{llllll}
\hline Bahan & F1 & F2 & F3 & F4 & F5 \\
\hline Hati ayam (g) & 40 & 120 & 200 & 280 & 360 \\
Tempe (g) & 360 & 280 & 200 & 120 & 40 \\
Tepung panir (g) & 150 & 150 & 150 & 150 & 150 \\
Telur (g) & 55 & 55 & 55 & 55 & 55 \\
Tepung terigu (g) & 75 & 75 & 75 & 75 & 75 \\
Bawang putih (g) & 15 & 15 & 15 & 15 & 15 \\
Garam (g) & 5 & 5 & 5 & 5 & 5 \\
Merica bubuk (g) & 3 & 3 & 3 & 3 & 3 \\
Ketumbar bubuk (g) & 3 & 3 & 3 & 3 & 3 \\
Pala bubuk (g) & 2 & 2 & 2 & 2 & 2 \\
Gula pasir (g) & 2 & 2 & 2 & 2 & 2 \\
\hline
\end{tabular}

\section{Tahap Pembuatan Produk Persiapan Bahan}

Telur dikocok lepas dan bumbu seperti bawang putih dikupas dan dihaluskan. Setelah itu, hati ayam, tempe dan bahan lainnya yang dibutuhkan, ditimbang sesuai dengan formulasi. Kemudian hati ayam dan tempe dilakukan penggilingan secara terpisah untuk mendapatkan tekstur yang lebih halus. Sebelum dilakukan penggilingan pada hati ayam, terlebih dahulu hati ayam dicuci menggunakan air mengalir untuk menghilangkan kotoran yang menempel. Kemudian dilakukan penggilingan hati ayam dengan blender selama \pm 20 detik dan ditambahkan dengan es batu. Setelah dilakukan penggilingan pada hati ayam, selanjutnya dilakukan penggilingan tempe. Tempe yang akan digiling terlebih dahulu dipotong. Setelah itu dilakukan pengukusan. Pengukusan dilakukan untuk menghentikan reaksi enzimatis dan fermentasi yang masih berlangsung pada tempe. Tujuan lain dari pengukusan adalah untuk mengurangi aroma langu dari tempe. 6

\section{Pembuatan Nugget}

Langkah awal pada pembuatan nugget yaitu pencampuran bahan utama yaitu hati ayam giling dan tempe giling hingga merata. Kemudian dilanjutkan dengan penambahan bahan-bahan lainnya seperti tepung terigu, telur, merica bubuk, ketumbar bubuk, pala bubuk, bawang putih, garam dan gula pasir. Selanjutnya setelah didapat adonan nugget, kemudian adonan dicetak dalam loyang yang telah dilapisi parchment paper. Parchment paper dipotong terlebih dahulu sesuai dengan ukuran loyang, kemudian diolesi dengan minyak goreng agar nugget tidak lengket setelah dikukus. Adonan nugget diratakan dengan ketebalan $\pm 3 \mathrm{~cm}$ untuk kemudian dilakukan pengukusan. 
Adonan nugget dikukus pada suhu \pm $100^{\circ} \mathrm{C}$ selama 30 menit. Kemudian didinginkan selama 15 menit pada suhu ruang lalu dipotong dengan ukuran $4 \mathrm{~cm} \mathrm{x}$ $3 \mathrm{~cm}$. Nugget yang telah dilakukan pemotongan selanjutnya dicelupkan ke dalam campuran tepung terigu, garam dan air yang disebut batter. Kemudian, nugget yang telah dicelupkan pada batter dilapisi dengan tepung panir. Selanjutnya dilakukan pengemasan dan dilanjutkan dengan pembekuan di dalam freezer pada suhu $-14^{\circ} \mathrm{C}$ yang menghasilkan nugget hati ayam kombinasi tempe beku.

\section{Uji Daya Terima}

Sebelum dilakukan daya terima, nugget beku yang telah didapatkan dari proses sebelumnya dilakukan penggorengan. Penggorengan dilakukan dengan metode deep frying pada suhu $180^{\circ} \mathrm{C}$ selama \pm 1 menit atau hingga warna nugget menjadi keemasan. Nugget kemudian ditiriskan selama 30 detik diatas kertas merang.

Uji daya terima dilakukan untuk menentukan formula terbaik nugget hati ayam kombinasi tempe. Panelis dalam uji daya terima terdiri dari 25 orang panelis yang sebelumnya telah mendapatkan mata kuliah mengenai uji organoleptik.

\section{Penentuan Formula Terpilih}

Penentuan formula terpilih dilakukan berdasarkan hasil uji organoleptik terkait daya terima nugget hati ayam kombinasi tempe secara keseluruhan dan dilakukan pembobotan pada setiap atribut mutu. Pembobotan ditentukan berdasarkan Metode Perbandingan Eksponensial (MPE) yang didasarkan pada atribut mutu yang paling penting. . Semakin penting atribut mutu, maka nilai pembobotan yang diberikan akan semakin besar. ${ }^{8}$

Atribut rasa memiliki bobot paling tinggi yaitu 35\% karena merupakan atribut mutu yang paling penting, tekstur 30\%, aroma $20 \%$ dan warna 15\%. ${ }^{9}$ Berdasarkan hasil uji daya terima, diketahui bahwa semua produk nugget hati ayam kombinasi tempe dapatditerima oleh panelis. Hal tersebut dapat dilihat dari nilai daya terima dari lima formula produk secara keseluruhan $>50 \%$. Suatu produk pangan dikatakan dapat diterima oleh konsumen apabila persentase konsumen yang menolak produk $<50 \%$ serta konsumen dapat mengonsumsi produk tersebut. ${ }^{10}$

\section{Uji Kadar Zat Besi}

Metode yang digunakan dalam analisis kandungan zat besi mengacu yaitu menggunakan metode Spektrofotometri Serapan Atom (SSA). Metode SSA dipilih berdasarkan pada tingkat kepekaan tinggi, kecepatan analisis, pelaksanaannya relatif sederhana dan dapat menentukan kadar suatu unsur dengan konsentrasi yang rendah. ${ }^{11}$

\section{Perhitungan Kontribusi Zat Gizi}

Perhitungan AKG dari kandungan zat besi nugget hati ayam kombinasi dihitung berdasarkan hasil laboratorium yang telah dilakukan sedangkan perhitungan kontribusi AKG dari energi, protein, lemak dan karbohidrat dihitung berdasarkan perhitungan estimasi menggunakan Tabel Komposisi Pangan Indonesia 2017.

\section{Rancangan Percobaan}

Penelitian ini adalah Rancangan Acak Lengkap (RAL) dengan tiga kali pengulangan perlakuan, dua kali pengulangan analisis serta lima taraf perlakuan. Lima taraf perlakuan berupa rasio kombinasi hati ayam dan tempe dalam pembuatan nugget. Perbandingan rasio antara hati ayam dan tempe yang digunakan adalah 10\%: 90\%, 30\% : 70\%, 50\% : 50\%, 30\% : 70\% dan 90\% : 10\%.

\section{Analisis Data}

Data hasil pengujian daya terima dianalisis normalitas data terlebih dahulu, apabila distribusi data menunjukkan tidak normal maka dilanjutkan dengan analisis Kruskal Wallis. Data hasil pengujian daya terima dianalisis dengan Kruskal Wallis. Apabila dari hasil uji dengan Kruskal Wallis menunjukkan adanya perbedaan nyata maka dilanjutkan dengan uji lanjutan Mann Whitney dengan tingkat kepercayaan 95\% $(\alpha=0.05)$ dari setiap perlakuan. Hasil analisis kadar zat besi menggunakan One Way Anova. 
Journal of Holistic and $\mathrm{Health} \mathrm{Sciences}$

Vol.3, No.2, Juli-D e s e m b e r $2019 \quad 69$

\section{Etika Penelitian}

Penelitian ini telah mendapat ethical clearance dari Komisi Etik Penelitian Kesehatan Universitas Pembangunan Nasional Veteran Jakarta dengan nomor B/2220/XI/2019/KEPK.

\section{HASIL PENELITIAN \\ Daya Terima}

Rerata kesukaan panelis terhadap nugget hati ayam kombinasi tempe disajikan pada Tabel 3.

Tabel 3. Rerata Tingkat Kesukaan Panelis Terhadap Warna Nugget Hati Ayam Kombinasi Tempe

\begin{tabular}{lllll}
\hline \multirow{2}{*}{ Formulasi } & \multicolumn{4}{c}{ Rerata } \\
\cline { 2 - 5 } & \multicolumn{1}{c}{ Warna } & \multicolumn{1}{c}{ Aroma } & \multicolumn{1}{c}{ Tekstur } & \multicolumn{1}{c}{ Rasa } \\
\hline 1 & $4 \pm 0.40^{\mathrm{a}}$ & $3.92 \pm 0.64^{\mathrm{a}, \mathrm{b}}$ & $3.32 \pm 0.74^{\mathrm{a}, \mathrm{b}}$ & $2.92 \pm 0.64^{\mathrm{a}}$ \\
2 & $3.76 \pm 0.83^{\mathrm{a}, \mathrm{b}}$ & $4.28 \pm 0.79^{\mathrm{c}}$ & $3.72 \pm 0.73^{\mathrm{a}, \mathrm{c}}$ & $3.56 \pm 0.65^{\mathrm{c}}$ \\
3 & $3.44 \pm 0.87^{\mathrm{b}, \mathrm{c}}$ & $4.16 \pm 0.68^{\mathrm{b}, \mathrm{c}}$ & $3.64 \pm 0.75^{\mathrm{a}, \mathrm{c}}$ & $4.16 \pm 0.85^{\mathrm{b}}$ \\
4 & $3.24 \pm 0.92^{\mathrm{c}, \mathrm{d}}$ & $3.8 \pm 0.76^{\mathrm{b}}$ & $3.24 \pm 0.97^{\mathrm{a}}$ & $3.56 \pm 1.08^{\mathrm{c}, \mathrm{d}}$ \\
5 & $3 \pm 0.86^{\mathrm{c}}$ & $3.6 \pm 0.91^{\mathrm{b}, \mathrm{d}}$ & $3.08 \pm 0.95^{\mathrm{b}}$ & $3.48 \pm 0.87^{\mathrm{c}, \mathrm{e}}$ \\
\hline & $p=0.000$ & $p=0.017$ & $p=0.049$ & $p=0.000$ \\
\hline
\end{tabular}

Keterangan : asi dengan huruf berbeda menunjukkan terdapat perbedaan signifikan $(p<0.05)$ 
Journal of Holistic and $\mathrm{Health} \mathrm{Sciences}$ Vol.3, No.2, Juli-D e s e m b e r $2019 \mid 70$

Penentuan Formula Terpilih

Hasil penentuan formula terpilih

berdasarkan daya terima produk secara keseluruhan dan metode pembobotan disajikan pada Tabel 4.

Tabel 4. Daya Terima Nugget Hati Ayam Kombinasi Tempe

\begin{tabular}{ccccccc}
\hline Formulasi & $\begin{array}{c}\text { Warna } \\
\mathbf{( 1 5 \% )}\end{array}$ & $\begin{array}{c}\text { Aroma } \\
\text { Aro\%) }\end{array}$ & $\begin{array}{c}\text { Tekstur } \\
\mathbf{( 3 0 \% )}\end{array}$ & $\begin{array}{c}\text { Rasa } \\
\mathbf{( 3 5 \% )}\end{array}$ & Nilai Total & $\begin{array}{c}\text { Persentase } \\
\text { Daya } \\
\text { Terima }\end{array}$ \\
\hline F1 & 0.53 & 0.70 & 1.06 & 1.23 & 3.52 & $70.4 \%$ \\
F2 & 0.57 & 0.76 & 1.14 & 1.34 & 3.81 & $76.2 \%$ \\
F3 & 0.57 & 0.77 & 1.15 & 1.34 & 3.83 & $76.6 \%$ \\
F4 & 0.55 & 0.74 & 1.11 & 1.29 & 3.69 & $73.8 \%$ \\
F5 & 0.49 & 0.65 & 0.98 & 1.15 & 3.27 & $65.4 \%$ \\
\hline
\end{tabular}

Keterangan : $\mathrm{F} 1$ = perbandingan hati ayam dan tempe 10\%: $90 \% \mathrm{~F} 2=$ perbandingan hati ayam dan tempe $30 \%: 70 \% \mathrm{~F} 3=$ perbandingan hati ayam dan tempe $50 \%: 50 \% \mathrm{~F} 4=$ perbandingan hati ayam dan tempe $70 \%: 30 \%$ F5 = perbandingan hati ayam dan tempe $90 \%: 10 \%$

\section{Kadar Zat Besi}

Rerata hasil pengujian kadar zat besi nugget hati ayam kombinasi tempe yang diurutkan berdasarkan urutan formula terpilih dapat dilihat pada tabel 5.

Tabel 5. Rerata Kadar Zat Besi Pada Nugget Hati Ayam Kombinasi Tempe

\begin{tabular}{cc}
\hline Formula Terpilih & Rerata Kadar Zat Besi (mg/100 g) \\
\hline F3 & $0.90 \pm 0.20$ \\
F2 & $0.96 \pm 0.61$ \\
F4 & $1.12 \pm 0.68$ \\
\hline & $p=0.877$ \\
\hline
\end{tabular}

Keterangan : F2 = perbandingan hati ayam dan tempe 30\%: 70\%

$\mathrm{F} 3=$ perbandingan hati ayam dan tempe 50\% : 50\% F4 = perbandingan hati ayam dan tempe $70 \%: 30 \%$

\section{Perhitungan Kontribusi Zat Gizi}

Tabel 6 Kandungan dan Kontribusi Zat Gizi Nugget Hati Ayam Kombinasi Tempe F3 (Perbandingan Hati Ayam dan Tempe 50\% : 50\%) Per Takaran Saji Terhadap AKG Kelompok Rentan

\begin{tabular}{|c|c|c|c|c|c|c|c|c|}
\hline \multirow[b]{2}{*}{ Zat Gizi } & \multirow{2}{*}{$\begin{array}{c}\text { Kandung an } \\
\text { Gizi Per } \\
\text { Takaran } \\
\text { Saji }\end{array}$} & \multicolumn{7}{|c|}{$\begin{array}{c}\text { Kontribusi terhadap AKG (\%) } \\
\text { Wanita Usia Subur }\end{array}$} \\
\hline & & $\begin{array}{c}1-3 \\
\text { tahun }\end{array}$ & $\begin{array}{l}\text { 4-5 } \\
\text { tahun }\end{array}$ & $\begin{array}{c}15 \\
\text { tahun }\end{array}$ & $\begin{array}{l}16-18 \\
\text { tahun }\end{array}$ & $\begin{array}{l}19-29 \\
\text { tahun }\end{array}$ & $\begin{array}{l}30-49 \\
\text { tahun }\end{array}$ & $\begin{array}{l}\text { Ibu } \\
\text { Hamil }\end{array}$ \\
\hline Energ & $170.4^{*}$ & 9.21 & 12.17 & 8 & 8 & 7.57 & 7.9 & 6.68 \\
\hline Protein (g) & $12.78^{*}$ & 63.9 & 51.12 & 19.66 & 19.66 & 21.3 & 21.3 & 14.2 \\
\hline Lemak (g) & $6.78^{*}$ & 15.06 & 13.56 & 9.68 & 9.68 & 10.43 & 11.3 & 12.08 \\
\hline Karbohidrat (g) & $22.56^{*}$ & 10.49 & 10.25 & 7.52 & 7.52 & 6.26 & 6.63 & 3.64 \\
\hline Zat Besi (mg) & $0.09^{* *}$ & 1.28 & 0.9 & 0.6 & 0.6 & 0.5 & 0.5 & 0.33 \\
\hline
\end{tabular}

Sumber : Kementerian Kesehatan, 2019; Kementerian Kesehatan, 2017 Keterangan : * : data perhitungan berdasarkan TKPI ; ${ }^{* *}$ : data perhitungan berdasarkan hasil analisis zat besi 
Journal of Holistic and $\mathrm{Health} \mathrm{Sciences}$

Vol.3, No.2, Juli-Desem b e r 2019 |71

Terhadap AKG Kelompok Rentan

\begin{tabular}{|c|c|c|c|c|c|c|c|c|}
\hline \multirow[b]{3}{*}{ Zat Gizi } & \multirow{3}{*}{$\begin{array}{c}\text { Kandungan } \\
\text { Gizi Per } \\
\text { Takaran Saji }\end{array}$} & \multicolumn{7}{|c|}{ Kontribusi terhadap AKG (\%) } \\
\hline & & \multicolumn{2}{|c|}{ Balita } & \multicolumn{3}{|c|}{ Wanita Usia Subur } & \multirow[b]{2}{*}{$\begin{array}{l}30-49 \\
\text { tahun }\end{array}$} & \multirow[b]{2}{*}{ Ibu Hamil } \\
\hline & & $\begin{array}{c}1-3 \\
\text { tahun }\end{array}$ & $\begin{array}{c}4-5 \\
\text { tahun }\end{array}$ & $\begin{array}{c}15 \\
\text { tahun }\end{array}$ & $\begin{array}{l}16-18 \\
\text { tahun }\end{array}$ & $\begin{array}{l}19-29 \\
\text { tahun }\end{array}$ & & \\
\hline Energi (kkal) & $135.78^{*}$ & 7.33 & 9.69 & 6.62 & 6.46 & 6.03 & 6.31 & 5.32 \\
\hline Protein (g) & $10.98^{*}$ & 54.9 & 43.92 & 16.89 & 16.89 & 18.3 & 18.3 & 12.2 \\
\hline Lemak $(\mathrm{g})$ & $6.01^{*}$ & 13.35 & 11.55 & 8.58 & 8.58 & 9.24 & 10.01 & 8.93 \\
\hline Karbohidrat (g) & $23.28^{*}$ & 10.82 & 10.58 & 7.76 & 7.76 & 6.46 & 6.84 & 5.82 \\
\hline Zat Besi (mg) & $0.096^{* *}$ & 1.37 & 0.96 & 0.64 & 0.64 & 0.53 & 0.53 & 0.35 \\
\hline
\end{tabular}

Sumber : Kementerian Kesehatan, 2019; Kementerian Kesehatan, 2017 Keterangan : * : data perhitungan berdasarkan TKPI ; ${ }^{* *}$ : data perhitungan berdasarkan hasil analisis zat besi

Tabel 8. Kandungan dan Kontribusi Zat Gizi Nugget Hati Ayam Kombinasi Tempe F4 Perbandingan Hati Ayam dan Tempe 70\% : 30\% Per Takaran Saji Terhadap AKG Kelompok Rentan

\begin{tabular}{|c|c|c|c|c|c|c|c|c|}
\hline \multirow[b]{3}{*}{ Zat Gizi } & \multirow{3}{*}{$\begin{array}{l}\text { Kandungan Gizi } \\
\text { Per Takaran Saji }\end{array}$} & \multicolumn{7}{|c|}{ Kontribusi terhadap AKG (\%) } \\
\hline & & \multicolumn{2}{|c|}{ Balita } & \multicolumn{3}{|c|}{ Wanita Usia Subur } & \multirow[b]{2}{*}{$\begin{array}{l}30-49 \\
\text { tahun }\end{array}$} & \multirow[b]{2}{*}{ Ibu Hamil } \\
\hline & & $\begin{array}{c}1-3 \\
\text { tahun }\end{array}$ & $\begin{array}{c}4-5 \\
\text { tahun }\end{array}$ & $\begin{array}{c}15 \\
\text { tahun }\end{array}$ & $\begin{array}{l}\text { 16-18 } \\
\text { tahun }\end{array}$ & $\begin{array}{l}19-29 \\
\text { tahun }\end{array}$ & & \\
\hline$\overline{\text { Energi (kkal) }}$ & $180.96^{*}$ & 9.78 & 12.92 & 8.82 & 8.61 & 8.04 & 8.41 & 8.51 \\
\hline Protein (g) & $14.04^{*}$ & 70.2 & 56.16 & 21.6 & 21.6 & 23.4 & 23.4 & 15.6 \\
\hline Lemak (g) & $6.47^{*}$ & 14.37 & 12.94 & 9.24 & 9.24 & 10.36 & 10.78 & 9.61 \\
\hline Karbohidrat (g) & $21.84^{*}$ & 10.15 & 9.92 & 7.28 & 7.28 & 6.06 & 6.42 & 5.46 \\
\hline Zat Besi (mg) & $0.112^{* *}$ & 1.6 & 1.12 & 0.74 & 0.74 & 0.62 & 0.62 & 0.41 \\
\hline
\end{tabular}

Sumber : Kementerian Kesehatan, 2019; Kementerian Kesehatan, 2017 Keterangan : * : data perhitungan berdasarkan TKPI $^{* *}$ : data perhitungan berdasarkan hasil analisis zat besi 


\section{PEMBAHASAN}

\section{Daya Terima Warna}

Hasil dari uji Kruskal Wallis menunjukkan bahwa formula yang paling disukai panelis untuk atribut warna yaitu F1 dan F2. Tingkat kesukaan panelis terhadap warna bagian dalam nugget hati ayam kombinasi tempe menunjukkan bahwa semakin tinggi persentase kombinasi tempe dan semakin sedikit persentase hati ayam, maka semakin disukai panelis. Pada pembuatan produk olahan hati ayam menunjukkan bahwa tingkat kesukaan panelis terhadap warna produk yang ditambahkan hati ayam lebih banyak memiliki nilai rerata paling rendah. Hal tersebut dikarenakan adanya peningkatan persentase hati ayam sehingga menimbulkan warna nugget menjadi coklat atau gelap. ${ }^{7}$

\section{Aroma}

Formula yang paling disukai panelis dalam atribut aroma yaitu F2 dengan persentase hati ayam dan tempe $30 \%$ : $70 \%$. Berdasarkan penelitian terdahulu menunjukkan bahwa nugget dengan penambahan hati ayam sebesar $20 \%$ lebih disukai dikarenakan tidak menghasilkan aroma yang amis. ${ }^{12}$

\section{Tekstur}

Formula nugget dengan tekstur yang lebih disukai panelis yaitu F2 yang memiliki tekstur kasar. Hal tersebut dikarenakan nugget dengan kombinasi tempe yang lebih banyak akan memiliki tekstur yang semakin kasar dan padat. ${ }^{13}$ Produk nugget dengan tekstur yang cukup kasar merupakan kriteria nugget dengan tingkat penerimaan konsumen yang tinggi. ${ }^{14}$

\section{Rasa}

Formula nugget hati ayam kombinasi tempe dengan atribut rasa yang paling disukai panelis yaitu F3 dengan rasio hati ayam dan tempe 50\% : 50\%. Semakin banyak komposisi hati ayam dalam suatu produk pangan, maka akan menimbulkan rasa pahit dari hati ayam yang lebih dominan dan kurang disukai oleh panelis. ${ }^{7}$ Maka dari itu, F3 dengan persentase hati ayam dan tempe yang sama kuantitasnya akan lebih diterima oleh panelis.

\section{Kadar Zat Besi}

Kandungan zat besi pada nugget hati ayam kombinasi tempe menunjukkan bahwa kandungan zat besi hasil analisis dalam produk nugget hati ayam kombinasi tempe lebih rendah dibandingkan dengan hasil estimasi perhitungan.

Hasil analisis kandungan zat gizi yang lebih rendah dibandingkan hasil perhitungan estimasi dapat disebabkan karena perhitungan estimasi zat besi dilakukan berdasarkan kandungan zat besi dari bahan mentah atau belum mengalami pengolahan sedangkan hasil analisis zat besi diperoleh dari bahan-bahan mentah yang diolah dan menghasilkan produk nugget hati ayam kombinasi tempe.15

Metode memasak dapat memberikan pengaruh terhadap perubahan kandungan zat besi dalam suatu makanan.14 Penelitian terdahulu menyebutkan bahwa kandungan zat besi dapat hilang sebesar $93.5 \%$ dalam proses pengukusan selama 4 menit serta penelitian lainnya menyebutkan bahwa kandungan zat besi pada makanan yang dikukus dapat hilang sebanyak $41.80 \%$ selama 20 menit dan $46.72 \%$ selama 30 menit.16-17 Pada penelitian ini persentase zat besi yang hilang pada produk nugget hati ayam kombinasi tempe yaitu sebesar $96.27-97.69 \%$.

\section{Kontribusi Zat Gizi Formula Terpilih Terhadap Pemenuhan AKG}

Suatu pangan dapat dikatakan tinggi zat besi apabila memiliki kandungan zat besi mencapai 30\% Acuan Label Gizi (ALG) per 100 gram dan dapat dikatakan sebagai sumber zat besi apabila memiliki kandungan zat besi mencapai 15\% ALG per 100 gram.18 Pada penelitian ini, nugget hati ayam kombinasi tempe memiliki 
kandungan dan kontribusi zat besi yang tergolong rendah dan tidak bisa dikatakan sebagai sumber zat besi. Kontribusi sebesar 0.32 - $1.4 \%$ masih belum mencukupi kebutuhan zat besi kelompok rentan yang berasal dari makanan selingan maupun makanan utama (10-25\% dari AKG). Maka dari itu, nugget hati ayam kombinasi tempe belum cocok dikonsumsi kelompok yang rentan anemia sebagai upaya pencegahan ataupun penanganan anemia karena rendahnya kandungan serta kontribusi zat besi.

Pada kontribusi protein, apabila kontribusi protein sebesar 20\% ALG per 100 gram, maka dapat dikatakan sebagai sumber protein dan kontribusi protein 35\% dari ALG per 100 gram dikatakan sebagai makanan tinggi protein. 18 Pada kelompok balita, nugget hati ayam kombinasi tempe dari ketiga formula terpilih dapat menjadi makanan tinggi protein karena protein berkontribusi sebesar 43,92-70,2\% sedangkan pada kelompok WUS dari nugget hati ayam kombinasi tempe F4 berkontribusi sebesar $21,6-23,4 \%$ sehingga dapat dikatakan sebagai sumber protein. Protein berperan penting dalam pembentukan eritrosit dan hemoglobin. Selain itu, protein juga berperan penting dalam transportasi zat besi di dalam tubuh. Apabila asupan protein kurang, maka proses pembentukan eritrosit dan hemoglobin akan terganggu serta transportasi zat besi terhambat. Sehingga dapat mengakibatkan terganggunya produksi sel darah merah dan dapat menyebabkan terjadinya anemia. ${ }^{19}$

\section{SIMPULAN}

Terdapat perbedaan daya terima nugget dari berbagai rasio hati ayam dan tempe serta tidak terdapat perbedaan kadar zat besi nugget dari berbagai rasio hati ayam dan tempe.

Pada penelitian ini diketahui bahwa kadar zat besi pada nugget masih rendah sehingga disarankan untuk dilakukan penelitian lebih lanjut untuk mendapatkan formulasi yang lebih baik serta modifikasi proses pengolahan dari nugget hati ayam kombinasi tempe agar kadar zat besi yang dihasilkan dapat dimanfaatkan sebagai upaya pencegahan serta penanggulangan anemia pada kelompok yang rentan mengalami anemia serta dapat menjadi pangan sumber zat besi.

\section{DAFTAR PUSTAKA}

1. Kementerian Kesehatan RI. Laporan Hasil Riset Kesehatan Dasar (Riskesdas) tahun 2013. Jakarta: Badan Penelitian dan Pengembangan Kesehatan Kemenkes RI. 2013.

2. Kementerian Kesehatan RI. Pedoman Pencegahan dan Penanggulangan Anemia Pada Remaja Putri dan Wanita Usia Subur (WUS). Direktorat Gizi Masyarakat Direktorat Jenderal Kesehatan Masyarakat Kementerian Kesehatan RI. 2016.

3. Moviana, R. Pembuatan Nugget dengan Penambahan Daun Kelor Sebagai Makanan Alternatif Makanan Tinggi Zat Besi. Jurnal UMUS Brebes, 2018; 1(1): 96-107.

4. Kementerian Kesehatan RI. Tabel Komposisi Pangan Indonesia 2017. Jakarta: Dirjen Kesehatan Masyarakat Direktorat Gizi Masyarakat. 2018.

5. Yuliana N, Pramono YB, Hintono B. Kadar Lemak, Kekenyalan dan Cita Rasa Nugget Ayam yang Disubstitusi Dengan Hati Ayam Broiler. Animal Agriculture Journal, 2013; 2(1): 301308.

6. Bastian F, Ishak E, Tawali AB, Bilang M. Daya Terima dan Kandungan Zat Gizi Formula Tepung Tempe Dengan Penambahan Semi Refined Carrageenan dan Bubuk Kakao. Jurnal Aplikasi Teknologi Pangan, 2013; 2(1).

7. Syahadah, M. M. Formulasi Sosis Tinggi Zat Besi dan Vitamin A dari Hati Ayam dan Wortel (Daucus Carota L.)Untuk Anak Usia Sekolah. Skripsi. Institut Pertanian Bogor. 2016.

8. Setyaningsih D, Apriyantono A, Sari 
MP. Analisis Sensori Untuk Industri Pangan dan Agro. Ciampea (ID): IPB Press. 2010.

9. Utiarahman G, Harmain RM, Yusuf N. (2013). Karakteristik Kimia dan Organoleptik Nugget Ikan Layang (Decapterus sp.) yang Disubtitusi dengan Tepung Ubi Jalar Putih (Ipomea batatas L). Jurnal Nike, 2013, $1(3)$.

10. Sianturi DP, Marliyati SA. Formulasi Flakes Tepung Komposit Pati Garut dan Tepung Singkong dengan Penambahan Pegagan Sebagai Pangan Fungsional Sarapan Anak Sekolah Dasar. Jurnal Gizi dan Pangan. 2014; 9(1).

11. Lestari S. Penetapan Kadar Besi dalam Kentang (Solanum tuberosum L.) Secara Spektrofotometri Serapan Atom. Thesis, Universitas Sumatera Utara. 2013.

12. Hamidiyah, Azizatul. Composition of Chicken Liver Nugget to Organoleptic and Hemoglobin Levels in the Efforts to Prevent Adolescent Female Anemia. 2018; 50(100): 250.

13. Permatasari PK. Nugget Tempe dengan Substitusi Ikan Mujair Sebagai Alternatif Makanan Sumber Protein, Serat dan Rendah Lemak. Skripsi. Diponegoro University. 2012.

14. Krismaputri ME, Hintono A, Pramono
YB. Kadar Vitamin A, Zat Besi (Fe) dan Tingkat Kesukaan Nugget Ayam yang Disubstitusi dengan Hati Ayam Broiler. Animal Agriculture Journal, 2013; 2(1), 288-294.

15. Lin J, Qi M, Peng X, Guo N, Yan X. Effects of Cooking Methods pn The Amino Acid and Mineral Contents in The Buds of Aralia Elata. CyTA-Journal of Food, 2018;16(1), 1089-1094.

16. Alonso MCB, Barrera PB. Variation of Food Mineral Content During Industrial and Culinary Processing. Handbook of Mineral Elements in Food, 2015; 163-176.

17. Armesto J, Gómez-Limia L, Carballo J, Martínez S. Effects of Different Cooking Methods on The Antioxidant Capacity and Flavonoid, Organic Acid and Mineral Contents of Galega Kale. International Journal of Food Sciences and Nutrition, 2019; 70(2): 136-149.

18. Badan Pengawas Obat dan Makanan. Pengawasan Klaim pada Label dan Iklan Pangan Olahan. BPOM. Jakarta: 2016.

19. Kusudaryati DPD, Prananingrum R. Hubungan Asupan Protein Dan Status Gizi Dengan Kadar Hemoglobin Pada Remaja Putri Anemia. Profesi (Profesional Islam): Media Publikasi Penelitian, 2018; 16(1), 47-52. 